\title{
Geological and geomorphological features of deep-seated catastrophic landslides in tectonically active regions of Asia and implications for hazard mapping
}

Disaster Prevention Research Institute, Kyoto University, Gokasho, Uji 611-001, Kyoto, Japan. E-mail: chigira@ slope.dpri.kyoto-u.ac.jp

Deep-seated catastrophic landslides, particularly rock or debris avalanches, travel extremely rapidly for long distances, causing severe damage over wide areas. This paper summarizes the geological and geomorphological features of such events, which were induced by earthquakes and rainstorms in Asia, and then uses these features to predict future potential sites of failures. Most of the rock avalanches are preceded by gravitational slope deformation with topographic features, in which small scarps along future head of landslide are the most representative; the scarps can be identified in topographic images made by highresolution airborne LiDAR DEMs and may suggest the instability just before catastrophic failure. Earthquakeinduced debris avalanches of pyroclastic fall deposits are not preceded by gravitational slope deformation but are of specific type and sequence of deposits, in which resilicified paleosol with halloysite may be the most important to accommodate a sliding surface.

\section{Introduction}

The numbers of lives lost in landslides in tectonically active regions is generally constantly large in comparison with those resulting from episodic earthquakes or volcanic eruptions (Petley, 2012), although the latter have received more attention as fatal natural hazards. In recognition of the fatal nature of landslides in such regions, the Japanese government changed its policies regarding earthquake prediction research after the 2011 Tohoku earthquake, to also include earthquake-induced hazards such as landslides, since research only on earthquakes cannot mitigate the associated hazards that contribute to the scale of such disasters. Most Asian countries are located in tectonically active, high-rainfall areas, and devastating landslides triggered by rainstorms, earthquakes, and snowmelt are frequent in many locations. Recent notable triggers include the 2011 typhoon Talas (Chigira et al., 2013b), 2011 Tohoku earthquake in Japan, 2009 typhoon Molakot in Taiwan (Tsou et al., 2011), 2009 Padang earthquake in Indonesia (Nakano et al., 2013), and 2008 Wenchuan earthquake and subsequent rainstorms in China (Chigira et al., 2010; Chigira et al., 2012a) (Table 1).

To mitigate landslide-induced disasters, it is necessary to know where and when landslides are likely to occur, and how and when to evacuate threatened areas prior to an event. Rock or debris slide avalanches are especially hazardous, and such events must be anticipated and prepared for, as they generally occur suddenly and travel quickly over long distances, affecting large areas. This paper focuses on the geological and geomorphological features of potential sites of rock or debris slide avalanches with respect to predicting the locations of these types of landslides.

Several approaches have been developed to predict potential sites of landslides, including those of physical modeling, stochastic modeling, and the indexing of geological and geomorphological features (Guzzetti et al., 1999). Physical modeling, such as slope stability analysis under conditions of heavy rainfall or an earthquake, requires information related for example to hydrological or geotechnical factors and subsurface structures, which are unavailable in many areas (Jibson et al., 1998; Montgomery et al., 2000). Stochastic modeling can be effective for investigating rather shallow landslides, which usually occur repeatedly in areas with particular geological characteristics, such as particular types of weathering profiles. In contrast, the occurrence of deep-seated catastrophic landslides is highly dependent on local and specific geological and/ or geomorphological conditions. Therefore, an understanding of the typology of these specific conditions may allow predictions regarding potential sites of rock and debris slides.

On the basis of our studies on the geological and geomorphological features of catastrophic rock and debris-slide avalanches in Asian countries, I have reached the conclusion that it is possible to predict at least the potential sites of such events. Most of the catastrophic rock-slide avalanches induced by either rainstorms or earthquakes are preceded by a particular type of gravitational slope deformation (Chigira, 1992; Dramis and Sorrisovalvo, 1994; Kilburn and Petley, 2003; Crosta et al., 2006; Chigira, 2009), whereas debris-slide avalanches caused by earthquake-induced failure of pyroclastic fall deposits are not (Chigira, 1982; Chigira et al., 2014). The latter, however, occur in areas of a particular type of pyroclastic succession characterized by heavily weathered pyroclastics or paleosol(s) at depth.

In this paper, I summarize the geological and geomorphological features of potential sites of deep-seated catastrophic landslides as a basis for establishing a methodology of landslide hazard mapping. 
Table 1. Recent landslide hazards in Asia

\begin{tabular}{|c|c|c|c|c|}
\hline Country & Trigger & Type of landslide & Fatality by landslides & References \\
\hline \multirow[b]{2}{*}{ China } & 2008 Wenchuan earthquake & Landslide on natural slopes & $>20000$ & Huang and Fan (2013) \\
\hline & $\begin{array}{l}\text { Rainstorms after the } 2008 \\
\text { Wenchuan earthquake }\end{array}$ & Debris flows & 3029 & $\begin{array}{l}\text { Chuan Tang (oral } \\
\text { communication) }\end{array}$ \\
\hline \multirow{2}{*}{ Taiwan } & 1999 Chi-Chi earthquake & $\begin{array}{l}\text { Landslide on natural and valley } \\
\text { fills of residential houses }\end{array}$ & $\begin{array}{l}\text { 39/Chiu-fen-erh-shan } \\
\text { 29/Tsaoling }\end{array}$ & $\begin{array}{l}\text { Chigira et al. (2003) } \\
\text { Wang et al. (2003) }\end{array}$ \\
\hline & Typhoon Molakot, 2009 & Landslide on natural slopes & $\begin{array}{l}\text { More than } 400 \text { by the } \\
\text { Shiaolin landslide }\end{array}$ & Tsou et al. (2011) \\
\hline Malaysia & Typhoon Greg, 1996 & Landslide on natural slope & 302 & $\begin{array}{l}\text { Lim Chounsian (oral } \\
\text { communication) }\end{array}$ \\
\hline Indonesia & 2009 Padang earthquake & Landslide on natural slopes & More than 400 & Nakano et al. (2013) \\
\hline Phillipines & 2006 Rain & Landslide on natural slopes & 1100 by Ginsaugon landslide & $\begin{array}{l}\text { Guthrie et al. (2009) } \\
\text { Evans et al. (2007) }\end{array}$ \\
\hline \multirow[t]{2}{*}{ Japan } & 2011 Tohoku earthquake & $\begin{array}{l}\text { Landslide on natural and valley } \\
\text { fills for residential houses }\end{array}$ & $\begin{array}{l}12 \text { by landslides (mostly by } \\
\text { tsunami) }\end{array}$ & Chigira et al. (2014) \\
\hline & Typhoon Talas, 2011 & Landslide of natural slopes & 56 by landslides & Chigira et al. (2013) \\
\hline
\end{tabular}

Catastrophic earthquake-induced landslides, such as those that have occurred in North America as a result of quick clay produced by glaciers (Hansen, 1965; Seed and Wilson, 1967), do not occur along the coastal regions of east or Southeast Asia, and therefore this type of landslide is not discussed here. Similarly, landslides induced by the collapse of large volcanic edifices, such as occurred during the 1982 Mt. Saint Helens event (Voight et al., 1983; Waitt et al., 1983), are related to volcanic activity, not rainfall or earthquakes, and therefore also lie outside the scope of this paper.

\section{Earthquake-induced landslides}

Recent earthquakes, such as the 2011 Tohoku earthquake in Japan, 2009 Padang earthquake in Indonesia, 2008 Wenchuan earthquake

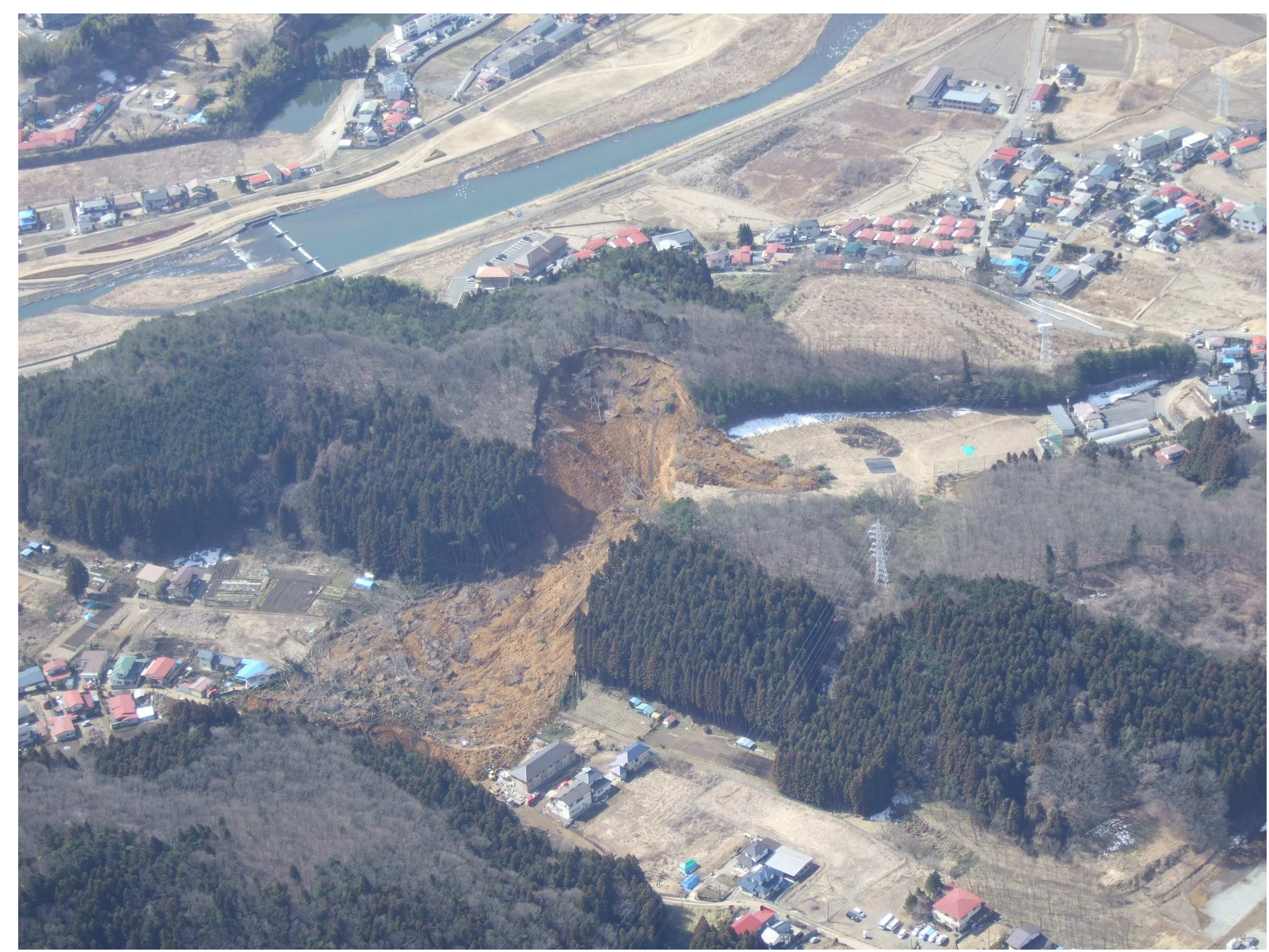

Figure 1. A typical catastrophic landslide induced by an earthquake on a slope of pyroclastic fall deposits. The Hanokidaira landslide induced by the 2011 Tohoku earthquake. (Photo courtesy: National Institute for Land and Infrastructure Management and Public Works Research Institute). 
in China, 2008 Iwate-Miyagi inland earthquake in Japan, 2005 northern Pakistan earthquake, and 2004 Mid-Niigata Prefecture earthquake in Japan, have proved of use in understanding where and why large catastrophic landslides are induced by earthquakes. These landslides have generally occurred where chemical weathering or gravitational deformation of rocks have preceded and reached nearthreshold conditions just prior to the catastrophic failure induced by earthquakes.

\section{Landslides prepared by chemical weathering processes}

\section{Pyroclastic fall deposits}

The 2011 Tohoku earthquake induced long-run-out catastrophic landslides in pyroclastic fall deposits with sliding surfaces in a halloysite-rich paleosol (Figure 1), which was originally formed by chemical weathering and then buried by subsequent pyroclastics. The paleosol, which had been formed by the leaching out of silica, alkali, and alkaline earth elements, reacted with percolating rainwater that had obtained silica during its infiltration through the new deposits, then resilicified and formed halloysite. This process is understood to be the primary reason for the occurrence of halloysite in these buried paleosols (Chigira, 1982; Kleber et al., 2007; Chigira et al., 2014). Similar landslides involving a sliding surface in a paleosol have occurred during many other earthquakes (Table 2), including the 2009 Padang earthquake. The largest landslide of pyroclastic fall deposits was the 1984 Ontake landslide induced by the Naganoken-Seibu earthquake in Japan with a volume of $36 \times 10^{6} \mathrm{~m}^{3}$ (Okuda et al., 1985). It had a sliding surface in halloysite-rich weathered pumice bed (Tanaka, 1985). The next largest was the Las Colinas landside, which had a volume of $1.83 \times 10^{5} \mathrm{~m}^{3}$, and which was induced by the 2001 El Salvador earthquake (Evans and Bent, 2004; Crosta et al., 2005); this landslide had a sliding surface in a paleosol even though clay minerals were not actually identified in that case. The distribution of halloysite-rich soil could be predicted by the study of both volcanostratigraphic characteristics and weathering mechanisms.

Landslides of this type do not occur on steep slopes because the pyroclastic fall deposits themselves do not form slopes steeper than the angle of repose, and such landslides may occur on gentle slopes even shallower than $20^{\circ}$ (Figure 2); these landslides are commonly very mobile with low equivalent coefficients of friction (Figure 2). Equivalent coefficients of friction are known to decrease with increasing landslide volume (Scheidegger, 1973; Hsu, 1975), but landslides of this type have exceptionally low values even for smallvolume landslides (Figure 3).

Table 2. A list of catastrophic landslides of pyroclastic fall deposits

\begin{tabular}{|c|c|c|c|c|c|c|c|c|c|}
\hline \multicolumn{2}{|l|}{ Earthquake } & $\begin{array}{l}1949 \\
\text { Imaichi }\end{array}$ & $\begin{array}{l}1968 \\
\text { Tokachi-Oki }\end{array}$ & $\begin{array}{l}1978 \text { Izu- } \\
\text { Oshima-Kinkai }\end{array}$ & $\begin{array}{l}1984 \text { Naganoken- } \\
\text { Seibu }\end{array}$ & $\begin{array}{l}2011 \\
\text { Tohoku }\end{array}$ & $\begin{array}{l}2001 \\
\text { El Salvador }\end{array}$ & $\begin{array}{l}2009 \\
\text { Padang }\end{array}$ & $\begin{array}{l}2008 \text { Iwate } \\
\text { Miyagi Inland }\end{array}$ \\
\hline \multicolumn{2}{|l|}{ Date } & 26 Dec. & 16 May & 14 Jan. & 14 Sept. & 11 March & 13 Jan. & 30 Sept. & 14 June \\
\hline \multicolumn{2}{|l|}{ Magnitude } & Mjma 6.4 & $\begin{array}{l}\text { Mjma7.9 } \\
(\text { Mw8.2) }\end{array}$ & Mjma 7.0 & Mjma 6.8 & Mw 9.0 & Mw 7.7 & Mw 7.5 & Mjma 7.2 \\
\hline \multicolumn{2}{|c|}{$\begin{array}{l}\text { Seismic Intensity } \\
\text { at landslide sites } \\
\text { (JMA) }\end{array}$} & $5 \sim 6$ & 5 & $5-6$ & 6 & $6-\sim 6+$ & $\begin{array}{l}\text { MM 6, } 7 \\
4,5-(J M A)\end{array}$ & $\begin{array}{l}\text { MM } 8 \text { (USGS) } \\
5+(\text { JMA) }\end{array}$ & $5+\sim 6+$ \\
\hline \multirow{4}{*}{$\begin{array}{l}\text { Antecedent } \\
\text { rain }(\mathrm{mm})\end{array}$} & $\begin{array}{l}\text { Rain } \\
\text { gauge }\end{array}$ & Utsunomiya & Hachinohe & Inatori & Ontakesan & Shirakawa & & & Komanoyu \\
\hline & 10 days & 22.5 & 181 & 12 & 183 & 12.5 & \multirow{3}{*}{$\begin{array}{l}\text { no data } \\
\text { (Nov.-Apr.: } \\
\text { dry season) })^{\mathrm{h}}\end{array}$} & \multirow{3}{*}{$\begin{array}{l}\text { Unknown } \\
\text { (occurred } \\
\text { during heavy } \\
\text { rain) }\end{array}$} & \multirow{3}{*}{$\begin{array}{l}89 \\
284.5 \\
388\end{array}$} \\
\hline & 30 days & 80.8 & 292 & 172 & 555 & 83.5 & & & \\
\hline & 60 days & 255 & 307 & 334 & 839 & 93.5 & & & \\
\hline \multicolumn{2}{|c|}{$\begin{array}{l}\text { Number of } \\
\text { collapsing landslide }\end{array}$} & $88^{\text {a) }}$ & $152^{\mathrm{b})}$ & $\begin{array}{l}7^{\mathrm{d})} \text { (controlled } \\
\text { by the material } \\
\text { distribution) }\end{array}$ & $5^{\mathrm{j})}$ & $<10^{\mathrm{e})}$ & $>1000^{\mathrm{g})}$ & $160^{\mathrm{i})}$ & $>100$ \\
\hline \multicolumn{2}{|c|}{ Sliding surface } & $\begin{array}{l}\text { Weathered } \\
\text { pumice } \\
\text { Halloysite }^{\text {a) }} \\
\text { Paleosol }^{\mathrm{m})}\end{array}$ & $\begin{array}{l}\text { Paleosol } \\
\text { (Sandy ash) } \\
\text { Halloysite }^{\text {c) }}\end{array}$ & $\begin{array}{l}\text { Paleosol } \\
\text { Halloysite }^{\mathrm{d})}\end{array}$ & $\begin{array}{l}\text { Weathered } \\
\text { pumice and } \\
\text { scoria } \\
\text { Halloysite }^{\mathrm{k})}\end{array}$ & $\begin{array}{l}\text { Paleosol } \\
\text { Halloysite }^{\mathrm{e})}\end{array}$ & $\begin{array}{l}\text { Paleosol }^{\mathrm{f})} \\
\text { No report of } \\
\text { clay minerals }\end{array}$ & $\begin{array}{l}\text { Mixed layer of } \\
\text { paleosol and } \\
\text { pumice } \\
\text { Halloysite }^{\text {i) }}\end{array}$ & $\begin{array}{l}\text { Various } \\
\text { Many in } \\
\text { weathered } \\
\text { pumice }\end{array}$ \\
\hline \multicolumn{2}{|c|}{ Slid material } & $\begin{array}{l}\text { Shichihonzakura } \\
\text { pumice and } \\
\text { Imaichi pumice }\end{array}$ & $\begin{array}{l}\text { Towada- } \\
\text { Hachinohe } \\
\text { tephra }^{\text {bc) }}\end{array}$ & $\begin{array}{l}\text { East Izu } \\
\text { monogenic } \\
\text { volcanic tephra }^{\text {d) }}\end{array}$ & $\begin{array}{l}\text { Scoria, lava, } \\
\text { agglutinate, } \\
\text { aterrace deposits, }\end{array}$ & $\begin{array}{l}\text { Tephra from } \\
\text { Nasu Volcano }^{\text {e) }}\end{array}$ & Pumice etc. & Pumice (Qhpt) & Various \\
\hline \multicolumn{2}{|c|}{$\begin{array}{l}\text { Source of the slid } \\
\text { materials }\end{array}$} & Nantai volcano & $\begin{array}{l}\text { Towada } \\
\text { Volcano } \\
\text { volcanoes }\end{array}$ & $\begin{array}{l}\text { Higashi-Izu } \\
\text { monogenetic }\end{array}$ & Ontake Volcano & Nasu Volcano ${ }^{1)}$ & $?$ & Tandikat Volcano ${ }^{\text {i) }}$ & Various \\
\hline \multicolumn{2}{|c|}{$\begin{array}{l}\text { Sliding surface } \\
\text { depth }(\mathrm{m})\end{array}$} & $3 \sim 5 \mathrm{~m}^{\mathrm{a})}$ & $\begin{array}{l}<3 \mathrm{~m}^{\mathrm{b})} \\
01 \sim 2.5 \mathrm{~m}^{\mathrm{c})}\end{array}$ & $2 \sim 6 \mathrm{~m}^{\mathrm{d})}$ & $\begin{array}{l}5 \mathrm{~m} \sim 200 \mathrm{~m} \\
\left.(\text { Ontake })^{\mathrm{j}}\right)\end{array}$ & $3 \sim 9 \mathrm{~m}^{\mathrm{e})}$ & $\begin{array}{l}50 \sim 70 \mathrm{~m} \\
(\text { Las Colinas })^{\mathrm{f}}\end{array}$ & $3.5 \sim 5.5 \mathrm{~m}^{\mathrm{i})}$ & - \\
\hline \multicolumn{2}{|c|}{$\begin{array}{l}\text { Slope-parallel } \\
\text { bedding }\end{array}$} & $\mathrm{O}$ & $\mathrm{O}$ & $\mathrm{O}$ & $\mathrm{O}$ & $\mathrm{O}$ & $\mathrm{O}$ & $\mathrm{O}$ & No \\
\hline \multicolumn{2}{|l|}{ Fatality } & 8 & 33 & 7 & 29 & 13 & $844^{\mathrm{g})}$ & $600 ?$ & $\mathrm{O}$ \\
\hline
\end{tabular}

Reference: a: Morimoto (1951); b: Inoue et al. (1970); c: Yoshida and Chigira (2012); d: Chigira (1982); e:Chigira et al. (2012); f: Crosta et al. (2005); g: Jibson et al. (2004); h: Evans and Bent (2004); i: Nakano et al. (2013); j: Hirano et al. (1985); k: Tanaka (1985); 1: Suzuki (1993); m: Chigira (unpublished data) 

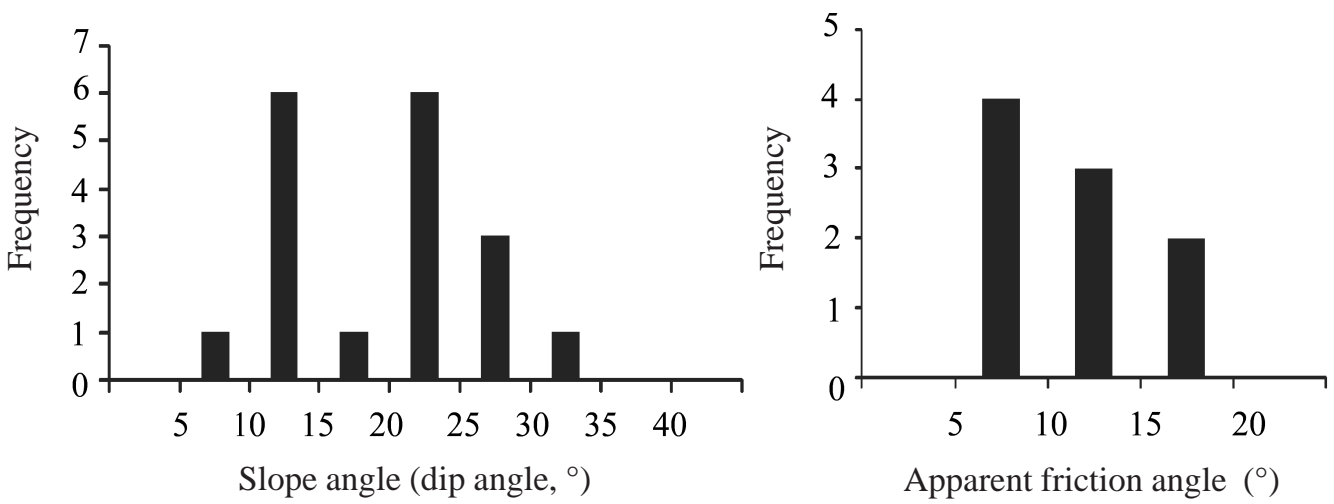

Figure 2. Slope angles and apparent friction angles of soilslide-avalanches of pyroclastic fall deposits. Data: 1923 Kanto earthquake (Kamai, 1990), 1968 Off Tokachi earthquake (Inoue et al., 1970), 1978 Izu-Oshima Kinkai earthquake (Chigira, 1982), 1984 NaganokenSeibu earthquake (Tanaka, 1985; Hirano et al., 1985), and 2011 off the Pacific coast of Tohoku earthquake.

\section{Carbonate rocks}

Carbonate rocks are easily dissolved by carbonic acid in groundwater, thereby leading to the formation of karstic landscapes with features such as caverns and dolines. The 2008 Wenchuan earthquake induced numerous landslides of carbonate rocks (Table 3; Huang, 2011; Huang and Fan, 2013). Many of these landslides occurred on the dip slopes of well-stratified carbonate rocks with sliding surfaces developed along bedding planes. The sliding surfaces commonly have rough surfaces with dimple-like depressions and fractured protrusions, with the depressions being formed by the dissolution of carbonates (Chigira et al., 2010) and fractured protrusions being formed at the contact between the overlying slide rock and the rock beneath. Groundwater flow along a bedding plane dissolves carbonates and decreases the areas of contact between rock masses above and below the surface; these contacts are finally broken by seismic shaking. The enlargement of pore spaces, in contrast, drains groundwater, and hence pore-water pressure build up is unlikely to occur during rainfall events. Catastrophic landslides of carbonate rocks were also induced in many places during the 2005 Kashmir earthquake (Sato et al., 2007).

\section{Mudstone}

Many slow-moving landslides in weak mudstone have been recorded in Japan, Malaysia, and Indonesia. These landslides are generally induced by melting snow or rainfall (Matsuura et al., 2008). Although rapid and catastrophic landslides of mudstone are generally not reactivated or newly induced by earthquakes, the 2004 mid-Niigata Prefecture earthquake triggered many such landslides in Neogene marine mudstone areas as well as in sandstone areas (Chigira and Yagi, 2005). Landslides in these areas may be related to the weathering of marine mudstone, whose weathering is dominated by the oxidation of pyrite (Chigira, 1990). Pyrite oxidation forms sulfuric acid, which in turn dissolves microfossils as well as other acid-labile minerals, and acts to deteriorate mudstone and to form micropores.

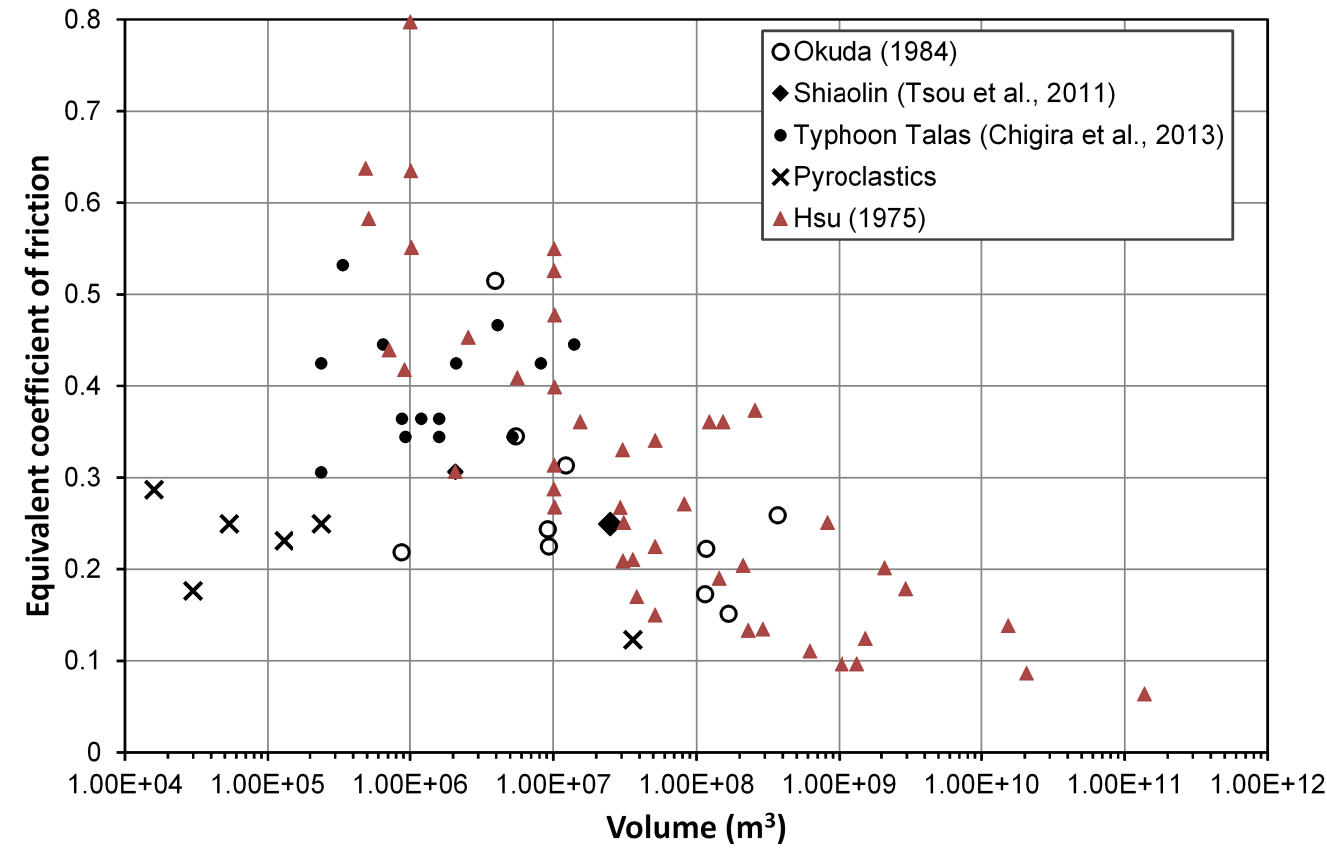

Figure 3. Equivalent coefficients of friction and landslide volumes. Landslides of pyroclastic fall deposits are plotted far below the trend of the other landslides.
Thus, weakened mudstone with many micropores might be sheared during an earthquake, generating abnormally high pore pressures, in turn leading to liquefaction of the sliding surface (Sassa et al., 1996). This may be a reasonable cause of a catastrophic landslide in mudstone.

\section{Mechanical preparation}

The mechanical preparation for large earthquake-induced landslides is deep-seated gravitational slope deformation, which has preceded many landslides. Such landslides include the Daguanbao landslide, which was triggered by the Wenchuan earthquake and is one of the largest historic landslides (Chigira et al., 2012b), and the Chiu-fen-erh-shan and Tsaoling landslides, which occurred during 
Table 3. List of earthquake-induced landslides of various rocks with special references to geologic structures and precursory landforms.

\begin{tabular}{|c|c|c|c|c|c|c|c|c|c|c|c|}
\hline Earthquake & Country & Magnitude & $\begin{array}{l}\text { Seismic intensity } \\
\text { at the landslide site }\end{array}$ & Landslide & $\begin{array}{l}\text { Volume } \\
\left(10^{6} \mathrm{~m}^{3}\right)\end{array}$ & $\begin{array}{l}\text { Rock } \\
\text { type }\end{array}$ & $\operatorname{dip}\left({ }^{\circ}\right)$ & Structure* & & $\begin{array}{l}\text { Precursory } \\
\text { landform }\end{array}$ & $\begin{array}{l}\text { Reference } \\
\text { Chigira }\end{array}$ \\
\hline $\begin{array}{l}715 \\
\text { earthquake }\end{array}$ & Japan & $\begin{array}{l}\text { M 6.5- } \\
7.5^{* *}\end{array}$ & Unknown & Ikeguchi & 93 & $\begin{array}{l}\text { Sandstone, } \\
\text { mixed rocks, } \\
\text { green stone }\end{array}$ & $50-60$ & UC & $\mathrm{Bt}$ & Head scarp & (2013) \\
\hline 1707 Hoei & Japan & M 8.4 & $5-6(\mathrm{JMA}) * *$ & Kanagi & 8.5 & $\begin{array}{l}\text { Sandstone, } \\
\text { mudstone }\end{array}$ & $60-90$ & A & FT & Furrows & $\begin{array}{l}\text { Chigira } \\
(2000)\end{array}$ \\
\hline $\begin{array}{l}1999 \\
\text { Chi-Chi }\end{array}$ & Taiwan & Mw 7.6 & $\begin{array}{l}465.3 \text { gal EW } \\
370.5 \text { gal NS, and } \\
274.7 \text { gal UD } \\
6 \mathrm{~km} \text { north of the } \\
\text { site }\end{array}$ & $\begin{array}{l}\text { Chiu-fen- } \\
\text { erh-shan }\end{array}$ & 50 & $\begin{array}{l}\text { Sandstone, } \\
\text { mudstone, } \\
\text { shale }\end{array}$ & $20-36$ & UC & B & $\begin{array}{l}\text { Linear } \\
\text { depression, } \\
\text { steps }\end{array}$ & $\begin{array}{l}\text { Wang et al. } \\
(2003)\end{array}$ \\
\hline \multirow{4}{*}{$\begin{array}{l}2004 \text { Mid } \\
\text { Niigata } \\
\text { Prefecture }\end{array}$} & \multirow[t]{4}{*}{ Japan } & \multirow[t]{4}{*}{$\begin{array}{l}\text { Mw } 6.6 \\
(\mathrm{Mj} 6.8)\end{array}$} & \multirow[t]{4}{*}{ 6+, 6-, 7 (JMA) } & $\begin{array}{l}\text { Higashitake- } \\
\text { zawa }\end{array}$ & 2 & $\begin{array}{l}\text { Sandstone, } \\
\text { mudstone }\end{array}$ & 20 & $\mathrm{OC}$ & $\mathrm{CU}$ & Head scarp & $\begin{array}{l}\text { Chigira and } \\
\text { Yagi (2005) }\end{array}$ \\
\hline & & & & Shiono & 5 & ditto & 14 & $\mathrm{OC}$ & $\mathrm{CU}$ & Head scarp & \\
\hline & & & & Terano & 0.5 & ditto & 14 & $\mathrm{OC}$ & $\mathrm{CU}$ & Head scarp & \\
\hline & & & & Kazefukitoge & 0.09 & ditto & $30-42$ & UC & B & Unknown & \\
\hline \multirow[t]{2}{*}{$\begin{array}{l}2005 \\
\text { Northern } \\
\text { Pakistan }\end{array}$} & \multirow[t]{2}{*}{ Pakistan } & \multirow[t]{2}{*}{ Mw 7.6} & \multirow[t]{2}{*}{ MM 8} & Dandbeh & 65 & $\begin{array}{l}\text { Sandstone, } \\
\text { mudstone }\end{array}$ & $\begin{array}{l}20 \text { (plunge } \\
\text { of a } \\
\text { syncline) }\end{array}$ & $\mathrm{OC}$ & $\mathrm{CU}$ & $\begin{array}{l}\text { Small } \\
\text { scarps }\end{array}$ & $\begin{array}{l}\text { Chigira } \\
\text { (2007), } \\
\text { Schneider } \\
(2008)\end{array}$ \\
\hline & & & & $\begin{array}{l}\text { Pir } \\
\text { Bandiwala }\end{array}$ & 1 & $\begin{array}{l}\text { Sandstone, } \\
\text { mudstone }\end{array}$ & Unknown & Unknown & $\mathrm{CU}$ & $\begin{array}{l}\text { Head } \\
\text { scarp }\end{array}$ & \\
\hline \multirow[t]{2}{*}{$\begin{array}{l}2008 \\
\text { Wenchuan }\end{array}$} & \multirow[t]{2}{*}{ China } & \multirow[t]{2}{*}{ Mw 7.9} & \multirow[t]{2}{*}{$\begin{array}{l}824.1 \text { gal EW, } \\
802.7 \text { gal NS and } \\
622.9 \text { gal UD }\end{array}$} & Daguanbao & 837 & $\begin{array}{l}\text { Carbonate } \\
\text { rocks }\end{array}$ & $\begin{array}{l}35-38 \\
\text { (oblique) }\end{array}$ & UC & B & $\begin{array}{l}\text { Linear } \\
\text { depression }\end{array}$ & $\begin{array}{l}\text { Chigira } \\
(2010)\end{array}$ \\
\hline & & & & Yinxinggou & Unknown & $\begin{array}{l}\text { Carbonate } \\
\text { rocks }\end{array}$ & $25 ?$ & $\mathrm{OC}$ & $\mathrm{U}$ & Unknown & \\
\hline $\begin{array}{l}2008 \text { Iwate } \\
\text { Miyagi } \\
\text { Inland }\end{array}$ & Japan & $\begin{array}{l}\text { Mw } 6.9 \\
(\mathrm{Mj} 7.2)\end{array}$ & $\begin{array}{l}328 \text { gal EW, } \\
413 \text { gal NS }\end{array}$ & Aratozawa & 67 & $\begin{array}{l}\text { Sandstone, } \\
\text { siltstone, tuff, } \\
\text { welded tuff }\end{array}$ & $0-2$ & $\mathrm{OC}$ & $\mathrm{CU}$ & $\begin{array}{l}\text { Linear } \\
\text { depression }\end{array}$ & $\begin{array}{l}\text { Ohno et al. } \\
(2010)\end{array}$ \\
\hline
\end{tabular}

*: OC: overdip cataclinal; UC: underdip cataclinal; A: anaclinal: Bt: buttress; B: buckling; FT: flexural toppling; U: undercut; CU: collided the opposite slope then undercut **: Usami (2003)

the 1999 Chi-Chi earthquake (Chigira et al., 2003; Wang et al., 2003). Deep-seated gravitational slope deformation reduces the strength of rocks forming the slope, which would then become more susceptible to mass movement triggered by earthquake tremors.

Gravitational slope deformations that precede and prepare a site for earthquake-induced catastrophic landslide failure include several particular types (Table 3). The Chiu-fen-erh-shan landslide was preceded by buckle folding on a convex dip slope (Wang et al., 2003, B in Table 3); deformation on this slope was expressed topographically as linear depressions and steps. Buckle folding occurs on underdip cataclinal slopes (Cruden, 1989), in which the slope dips in the same direction as the dip of the foliation but with a gentler angle. Buckle folding can significantly destabilize a slope when it proceeds with the overturning of the lower limb of the fold, because when the lower limb is broken the whole slope loses its support at the foot. Landslides of this type, such as the Kazefukitoge landslide, also occurred during the 2004 Mid-Niigata Prefecture earthquake (Chigira and Yagi, 2005), and are also reported to have preceded the Daguanbao landslide, the largest landslide induced by the 2008 Wenchuan earthquake (Chigira et al., 2010). The Qingping landslide induced by the Wenchuan earthquake occurred on an underdip cataclinal slope and formed a landslide dam. This landslide left clearly observed buckle folding on the landslide scar (Figure 4).

A special type of underdip cataclinal slope that may become the site of an earthquake-induced landslide is a buttress-type structure, in which resistant beds at the foot of the slope support the upper part of the slope (Bt in Table 3). A well-known case is the Madison landslide, which was triggered by the 1959 Hebgen Lake earthquake in the USA (Hadley, 1964). In that case, heavily weathered gneiss and schist were supported by dolomite in the lower part of the slope, but the shaking of the earthquake broke the support and the whole slope failed. Whether gravitational slope deformation occurred before the event is not known. An earthquake-induced landslide with a similar buttress structure was the Ikeguchi landslide induced by the AD 715 earthquake in central Japan (Chigira, 2013). On the slope that hosted the landslide, beds of mixed rock and greenstone were supported by a thick, massive sandstone bed at the foot, which eventually failed because of seismic motion. The topography prior to the landslide is inferred from an adjacent slope, where the mixed rocks and greenstone 

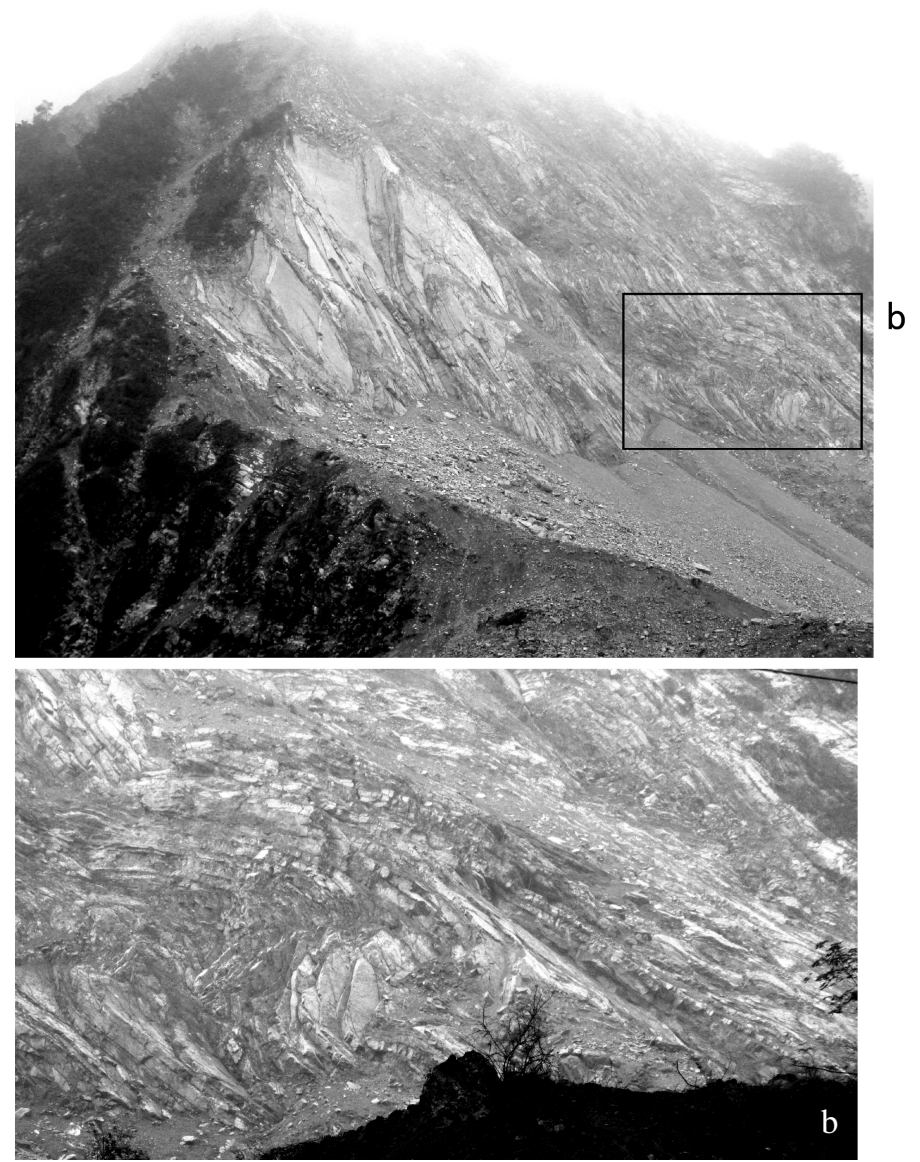

Figure 4. A buckle fold on the landslide scar of the Qingping landslide, which was induced by the 2008 Wenchuan earthquake and formed a landslide dam.

beds have been displaced downslope but remain supported by a thick sandstone bed, leaving a small scarp along the ridge. Gravitational slope deformation almost certainly preceded the catastrophic failure in $\mathrm{AD} 715$.

An overdip cataclinal slope, in which a slope dips in the same direction as the bedding but more steeply (OC in Table 3), may be subject to gradual sliding, forming a linear depression or a scarp upslope. The Tsaoling landslide induced by the 1999 Chi-Chi earthquake had an overdip cataclinal slop structure, and linear depressions had developed along the position of its future crown before the earthquake. The Bairaman landslide induced by the 1985 earthquake in Papua New Guinea had a structure and linear depression upslope similar to that of the Tsaoling landslide (King et al., 1989).

Another type of landslide frequently triggered by earthquakes is the reactivation of a previous landslide that ran out across a river from one side of the valley and collided with the opposing slope, and which was subsequently undercut by erosion (CU in Table 3 ). The reactivation occurs because the support of the upslope material is removed, and therefore the landslide body becomes unstable. This type of landslide occurred in many locations during the 2004 MidNiigata Prefecture earthquake in Japan (Chigira and Yagi, 2005). The Hattian landslide, which was triggered by the 2005 northern Pakistan earthquake, had similar characteristics (Chigira, 2007; Dunning et al., 2007; Schneider, 2008).

\section{Landslides induced by water blow-out during earthquakes}

A distinctive type of landslide was induced by the 1966 Matsushiro earthquake, which caused groundwater to gush out along seismogenic faults, with the rise in water pressure inducing rotational landslides (Morimoto et al., 1967). Faults may locally cause groundwater pressure to build up by the accumulation of tectonic strain on them (Sibson, 1996), and the affected areas are in some situations more than $100 \mathrm{~km}$ away from the source fault (Toda et al., 1995). The locations of induced landslides are, however, limited to those areas close to surface fault ruptures.

\section{Preceding rainfall}

Rainfall that precedes an earthquake (antecedent rainfall) is known to be a significant influence on the occurrence of landslides, because the groundwater level can rise and decrease the suction forces within soil through the development of positive pore water pressure. The 2004 mid-Niigata Prefecture earthquake, Japan, triggered about 100 landslides with volumes exceeding $10^{5} \mathrm{~m}^{3}$ (Chigira and Yagi, 2005), but the 2007 Noto-hanto and the 2007 off-mid-Niigata Prefecture earthquakes induced very low numbers of landslides, even though these earthquakes had similar seismic intensities in the areas with similar geological and geomorphological settings to those of the 2004 mid-Niigata Prefecture earthquake (Table 4). The observed difference in landslide occurrence has been explained in terms of the rainfalls preceding these earthquakes (Chigira, 2007): the 2004 mid-Niigata Prefecture earthquake was preceded by more than $100 \mathrm{~mm}$ of rainfall within the three days prior to the earthquake, but the other two earthquakes were preceded by much smaller amounts of rainfall (Figure 5).

The occurrence of landslides in pyroclastic fall deposits is also strongly influenced by antecedent rainfall. The 2011 Tohoku earthquake caused shaking with intensities of $>6$ on the Japan Meteorological Agency scale over wide areas, but triggered fewer than 10 landslides on slopes formed from pyroclastic fall deposits. Comparing the rainfall amounts for 10, 30, and 60 days before the earthquakes that induced landslides in pyroclastic fall deposits (Table 2, Figure 6), the 2011 Tohoku earthquake was characterized by having the smallest amounts in all three intervals. The 1949 Imaichi earthquake had similar rainfall amounts during the 10- and 30-day intervals to those of the 2011 Tohoku earthquake, but induced 88 landslides in pyroclastic fall deposits. The materials of landslides induced by both of these earthquakes are widely distributed (Suzuki, 1993), so more landslides would have been triggered if factors other than seismic shaking had been close to their critical values for slope instability. These factors include antecedent rainfall, slope direction, undercutting conditions, and seismic behavior (Chigira, 1982); of these factors, antecedent rainfall is likely to be the most influential when a large area is considered. The 1978 Izu-Oshima-Kinkai earthquake induced only seven landslides, but these landslides were densely packed within an area of $1.5 \mathrm{~km}^{2}$, wherein materials sourced from nearby monogenic volcanoes were distributed (Chigira, 1982). The 1984 Naganoken-Seibu earthquake induced only five landslides, but these were huge and the largest landslide had a volume of 36 million $\mathrm{m}^{3}$ (Okuda et al., 1985). Notably, the Naganoken-Seibu earthquake was preceded by a much greater amount of rainfall than those earthquakes listed in Table 2. 
Table 4. A comparison among the earthquakes that affected the areas with similar geologic and topographic settings. Only 2004 the Mid Niigata Prefecture earthquake induced many large landslides.

\begin{tabular}{|c|c|c|c|c|c|c|c|c|}
\hline Earthquake & Date & $\begin{array}{l}\text { Magnitude } \\
\quad(\mathrm{Mj})\end{array}$ & $\begin{array}{c}\text { Seismic } \\
\text { intensity } \\
\text { (JMA) }\end{array}$ & $\begin{array}{l}\text { Fault } \\
\text { type }\end{array}$ & $\begin{array}{l}\text { Rock } \\
\text { types }\end{array}$ & Age & $\begin{array}{l}\text { Landslide } \\
\text { numbers }\end{array}$ & Reference \\
\hline $\begin{array}{l}\text { Mid Niigata } \\
\text { Prefecture EQ in } 2004\end{array}$ & 23 Oct. & 6.8 & $6-\sim 7$ & Reverse & $\begin{array}{l}\text { Sedimentary } \\
\text { rocks }\end{array}$ & $\begin{array}{l}\text { Neogene and } \\
\text { younger }\end{array}$ & $\begin{array}{l}\text { More than } 100 \\
\text { large landslides }\end{array}$ & $\begin{array}{l}\text { Chigira and Yagi } \\
(2006)\end{array}$ \\
\hline $\begin{array}{l}\text { Noto Peninsula } \\
\text { EQ in } 2007\end{array}$ & 25 March & 6.9 & $6-\sim 6+$ & Reverse & $\begin{array}{l}\text { Sedimentary } \\
\text { rocks } \\
\text { Volcanic rocks }\end{array}$ & $\begin{array}{l}\text { Neogene and } \\
\text { younger }\end{array}$ & $\begin{array}{l}\text { A few large } \\
\text { landslides }\end{array}$ & \\
\hline $\begin{array}{l}\text { Off Mid Niigata } \\
\text { Prefecture EQ in } 2007\end{array}$ & 16 July & 6.8 & $6+$ & Reverse & $\begin{array}{l}\text { Sedimentary } \\
\text { rocks }\end{array}$ & $\begin{array}{l}\text { Neogene and } \\
\text { younger }\end{array}$ & $\begin{array}{l}\text { A few large } \\
\text { landslides }\end{array}$ & \\
\hline
\end{tabular}

The effects of antecedent rainfall on earthquake-induced landslides have also been reported from New Zealand (Dellow and Hancox, 2006). The 1929 Buller and the 1931 Hawke's Bay earthquakes were both of Ms 7.8 and induced landslides in areas of intensities of 9 and 10 on the Modified Mercalli Intensity scale, but the former earthquake induced much larger and greater numbers of landslides. The Buller earthquake was preceded by $183.9 \mathrm{~mm}$ of rainfall over 10 days but the Hawke's Bay earthquake by only 8.4 $\mathrm{mm}$. The geological and physiographical settings differed between these two areas, but soil moisture conditions are likely to have accounted for at least some of the difference in landslide occurrence between these two events. In Pakistan, Petley et al. (2006) reported that the 2005 northern Pakistan earthquake induced rather a low number of landslides because the amount of antecedent rainfall was small.

The effects of antecedent rainfall on landslide occurrence, as discussed above, must be considered when a landslide hazard map is constructed on the basis of historical records, because the pattern and number of landslides induced by previous earthquakes might have been very different if those earthquakes had been preceded by smaller or larger amounts of rainfall. The time intervals for the evaluation of antecedent rainfall that must be accounted for may depend on geological conditions. For example, weathered pyroclastic materials should retain water for much longer than sandy materials.

Table 5. A list of rainstorms that induced deep-seated catastrophic landslides or many shallow landslides in Japan.

\begin{tabular}{|c|c|c|c|c|c|c|}
\hline Year & Date & Trigger(T: typhoon) & Place (Prefecture) & Geology & $\begin{array}{l}\text { Deep-seated } \\
\text { landslide }\end{array}$ & $\begin{array}{l}\text { Many Shallow } \\
\text { landslides }\end{array}$ \\
\hline 1998 & 26 to 31 August & Rain (Front) & Fukushima & $\begin{array}{l}\text { Vapor-phase crystallized } \\
\text { ignimbrite }\end{array}$ & - & $\mathrm{O}$ \\
\hline 1999 & 29 June & Rain (Baiu front) & Hiroshima & Granite & - & $\mathrm{O}$ \\
\hline 2000 & $\begin{array}{l}\text { 28-29 July } \\
11-12 \text { Sept. }\end{array}$ & $\begin{array}{l}\text { Rain (Front) } \\
\text { Rain (Front+T14) }\end{array}$ & $\begin{array}{l}\text { Rumoi (Hokkaido) } \\
\text { Tokai (Aichi) }\end{array}$ & $\begin{array}{l}\text { Soft sedimentary rocks } \\
\text { Granite }\end{array}$ & $\begin{array}{l}- \\
-\end{array}$ & $\begin{array}{l}\mathrm{O} \\
\mathrm{O}\end{array}$ \\
\hline 2003 & $\begin{array}{l}20 \text { July } \\
\text { 9-10 August } \\
\text { Ditto }\end{array}$ & $\begin{array}{l}\text { Rain (Baiu Front) } \\
\text { Rain (T10) } \\
\text { Ditto }\end{array}$ & $\begin{array}{l}\text { Minamata (Kumamoto) } \\
\text { Hishikari (Kagoshima) } \\
\text { Hidaka (Hokkaido) } \\
\text { Ditto }\end{array}$ & $\begin{array}{l}\text { Andesite lava and pyroclastics } \\
\text { Sandstone and conglomerate } \\
\text { Melange }\end{array}$ & $\begin{array}{l}\text { O } \\
- \\
-\end{array}$ & $\begin{array}{l}\mathrm{O} \\
\mathrm{O} \\
\mathrm{O}\end{array}$ \\
\hline 2004 & $\begin{array}{l}13 \text { July } \\
\text { Ditto } \\
28-29 \text { Sept. } \\
1 \text { Aug. } \\
29 \text { Sept. } \\
29 \text { Sept. }\end{array}$ & $\begin{array}{l}\text { Rain (Baiu front) } \\
\text { Ditto } \\
\text { Rain (T21) } \\
\text { Rain (T10) } \\
\text { Rain (T21) } \\
\text { Rain (T21) }\end{array}$ & $\begin{array}{l}\text { Nagaoka (Niigata) } \\
\text { Fukui } \\
\text { Miyagawa (Mie) } \\
\text { Kisawa (Tokushima) } \\
\text { Ehime-Kagawa } \\
\text { Saijo (Ehime) } \\
\end{array}$ & $\begin{array}{l}\text { Weak mudstone } \\
\text { Volcanic rocks } \\
\text { Accretional complex (Hard } \\
\text { sedimentary rocks) } \\
\text { Accretional complex } \\
\text { (Greeenstone and hard } \\
\text { sedimentary rocks) } \\
\text { Heavily weathered hard } \\
\text { sandstone and mudstone } \\
\text { Schist }\end{array}$ & $\begin{array}{l}- \\
- \\
\mathrm{O} \\
\mathrm{O}\end{array}$ & $\begin{array}{l}\mathrm{O} \\
\mathrm{O} \\
- \\
-\end{array}$ \\
\hline 2005 & 6 Sept. & Rain (T14 (Nabi)) & Mimikawa (Miyazaki) & $\begin{array}{l}\text { Accretional complex (Hard } \\
\text { sedimentary rocks) }\end{array}$ & $\mathrm{O}$ & - \\
\hline 2006 & 19 July & Rain (Baiu front) & Okaya (Nagano) & Loam & - & $\mathrm{O}$ \\
\hline 2009 & 21 July & Rain (Baiu front) & Hofu (Yamaguchi) & Granite & - & $\mathrm{O}$ \\
\hline 2010 & 16 July & Rain (Baiu front) & Shobara (Hiroshima) & Soil & - & $\mathrm{O}$ \\
\hline 2011 & 4 Sept. & Rain (T12 - Talas) & $\begin{array}{l}\text { Kii Mountains (Nara } \\
\text { Wakayama) }\end{array}$ & $\begin{array}{l}\text { Accretional complex (Hard } \\
\text { sedimentary rocks) }\end{array}$ & $\mathrm{O}$ & - \\
\hline 2012 & 12 July & Rain (Baiu front) & Aso (Kumanoto) & Volcanic ash & - & $\mathrm{O}$ \\
\hline 2013 & 16 Oct. & Rain (T26 - Wipha) & Izu-Oshima (Tokyo) & Volcanic ash & - & $\mathrm{O}$ \\
\hline
\end{tabular}



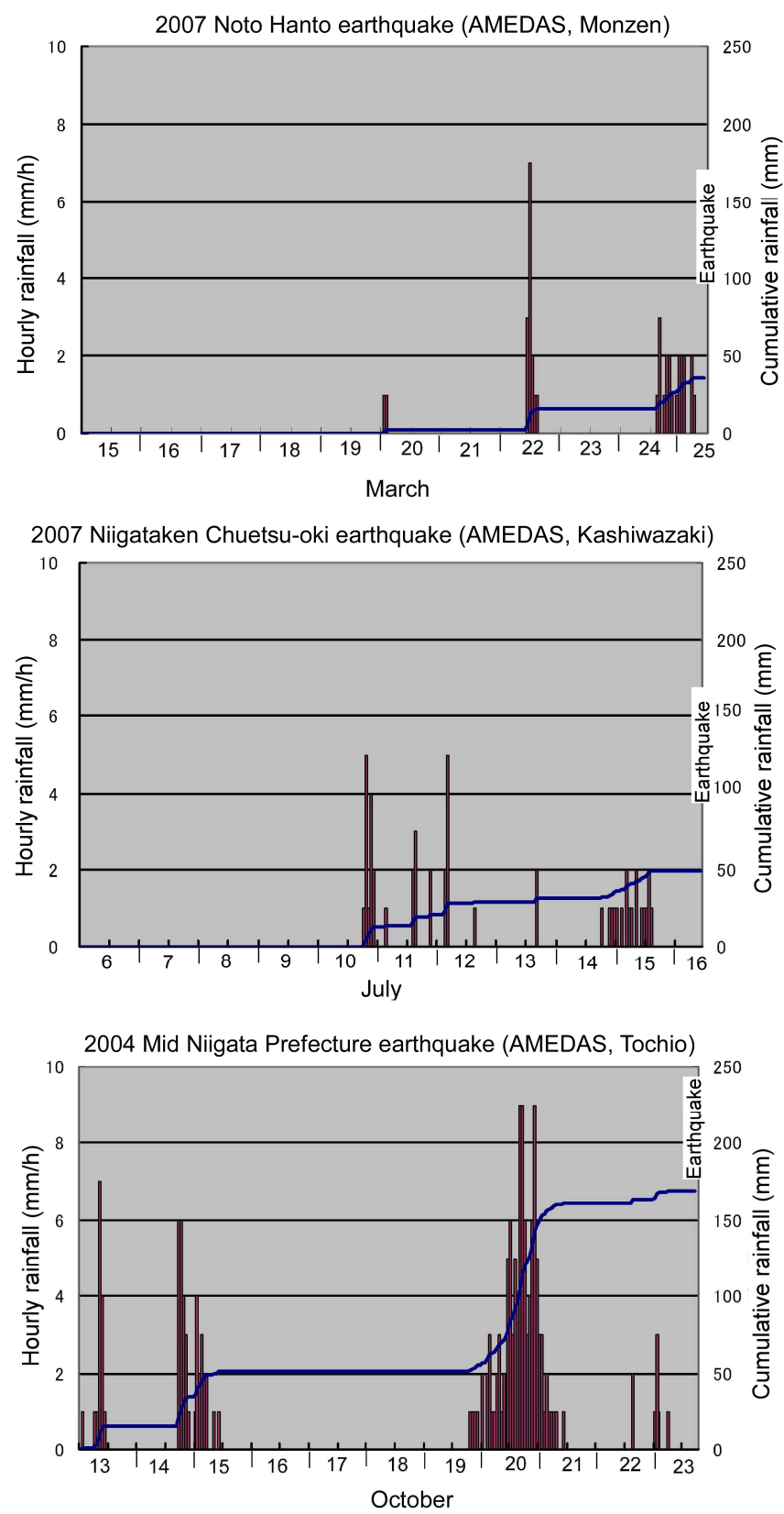

Figure 5. Antecedent rainfalls before the 2005 Mid Niigata Prefecture earthquake that induced many deep-seated landslides and other two earthquakes that induced much less numbers of landslides. See text for the details.

Thus, a longer time frame for considering the effects of antecedent rainfall may need to be considered when evaluating the effects of antecedent rainfall and earthquakes with respect to mapping landslide hazards.

\section{Rainfall-induced landslides}

In addition to the occurrence of earthquakes, most Asian countries are located in rainy areas, where large amounts of precipitation increase the probability of landslide occurrence. To predict the potential sites of shallow landslides, the effects of rainstorms have been studied deterministically using physical models (Montgomery and Dietrich, 1994; Montgomery et al., 2000). However, such

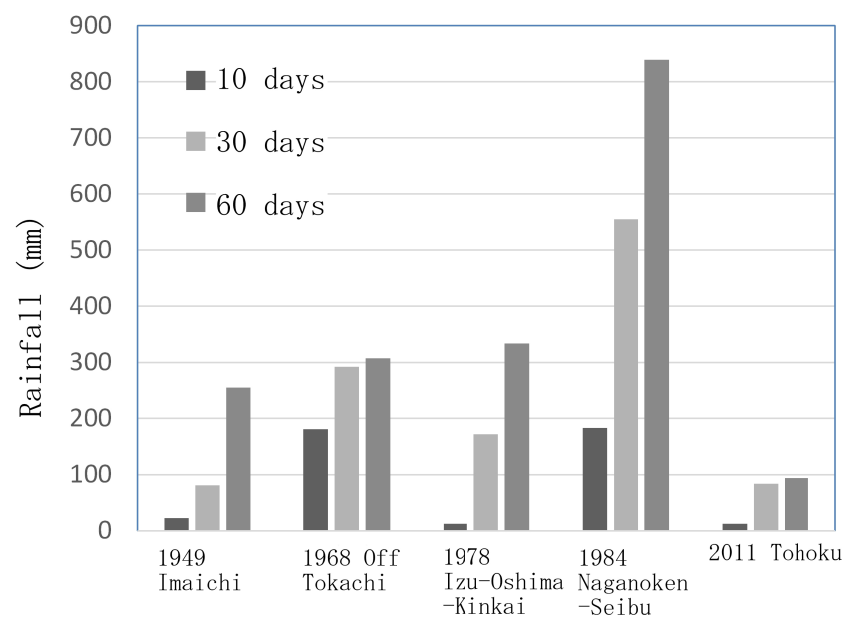

Figure 6. Antecedent rainfalls before the earthquakes that induced catastrophic landslides of pyroclastic fall deposits.

modeling needs data on both slope geometry and mechanical properties, which vary widely and are often not able to be estimated appropriately. Potential sites of shallow landslides may thus not be easily identified. In contrast, deep-seated landslides occur on slopes with very site-specific geological and geomorphological conditions; many such landslides are characterized by prior gravitational slope deformation (Chigira, 2009; Chigira et al., 2013b).

Deep-seated catastrophic landslides induced by typhoon Talas 2011 in Japan were significant, because ten were surveyed using 1-m high-resolution digital elevation models (DEMs) before the landslide events (Chigira et al., 2013b). These landslides occurred mainly in the Shimanto Belt, which is underlain by Cretaceous to Paleogene accretion complexes represented by mixed rocks and broken formations. In a recent study, Chigira et al. (2013b) analyzed the topography existing prior to the catastrophic failures triggered by typhoon Talas, and the results have shown that the catastrophic failures were preceded by gravitational slope deformation. Chigira (2013) analyzed the pre-typhoon Talas topography for an additional 29 catastrophic landslides using high-resolution DEMs and found that they were all preceded by gravitational deformation. Twentysix of the total of 39 deep-seated catastrophic landslides had small scarps marking the positions of the heads of the subsequent landslides (Figure 7, Chigira, 2013). These scarps were caused by gravitational slope deformation that preceded the catastrophic failure. Although the scarps may have been enlarged by degradation, their sizes relative to the whole slopes suggest that minimal amounts of slope deformation had occurred in the period immediately before the catastrophic failure. The scarp ratio, defined as the ratio of the length of a scarp to that of the whole slope, both measured along the slope line, ranged from $1 \%$ to $23 \%$. Amongst landslides with small scarps, $38 \%$ had scarp ratios of $<4 \%$ and $50 \%$ had scarp ratios of $<8 \%$. These data suggest that the gravitational slope deformations that preceded catastrophic failures were relatively small, and indicate that the slopes involved were likely to have been at critical condition just prior to catastrophic failure. Typical landslides featuring these small scarps occurred on slopes with wedge-shaped discontinuities dominated by thrust surfaces that were undulating and which discontinuously sandwiched competent rocks of sandstone, chert, or greenstone. The sliding surfaces that appeared just after catastrophic failure had undulating and stepped surfaces, which strongly suggests that the slopes before failure included materials that resisted whole-slope sliding. These stepped 
a

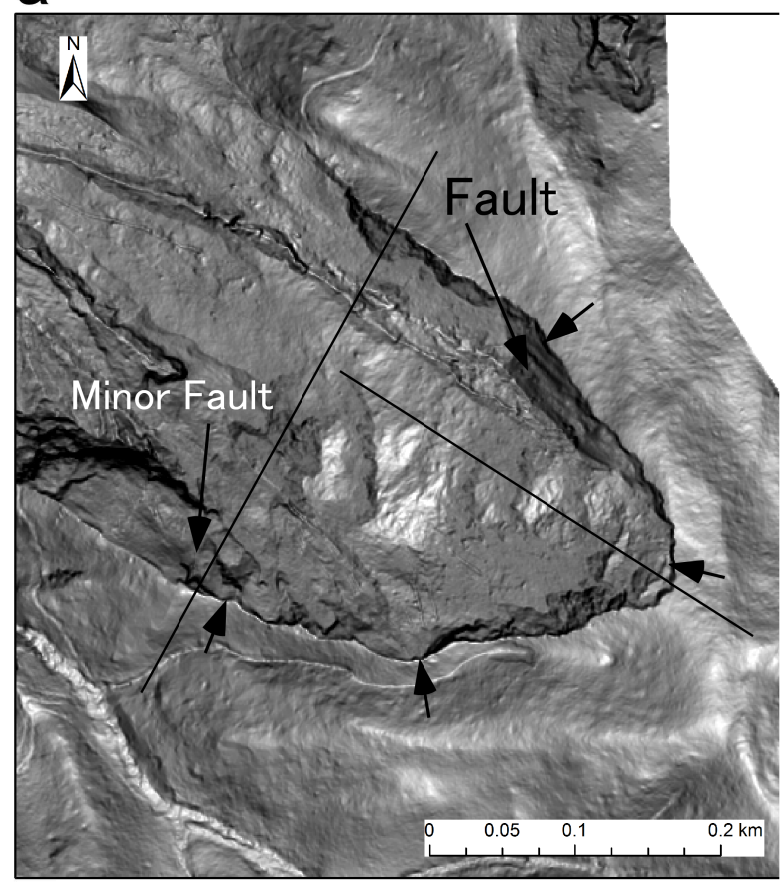

C

Elevation (masl)

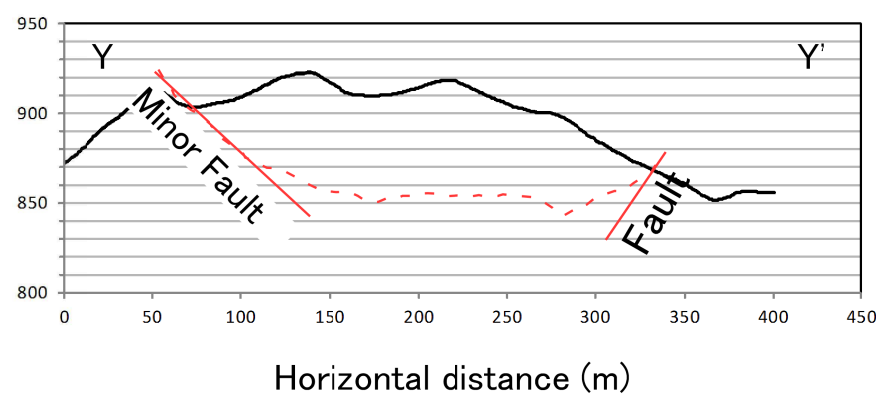

b

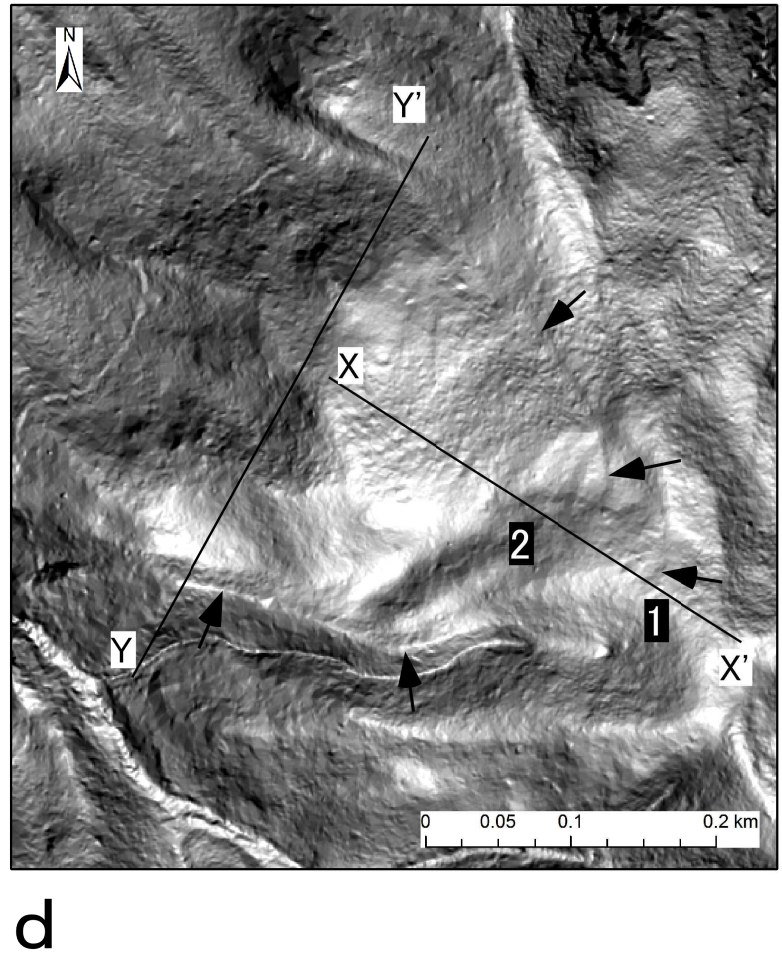

Elevation (masl)

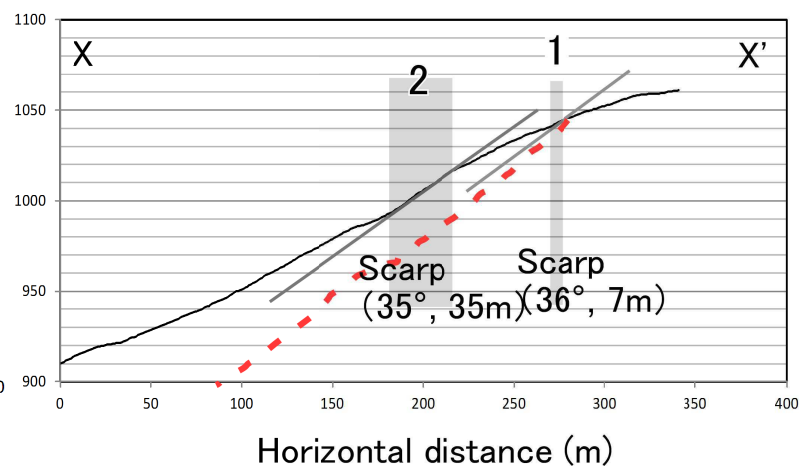

Figure 7. Slope images and cross sections of the upper part of the Akatani landslide induced by the 2011 typhoon Talas. a) After the landslide. b) Before the landslide. c) Cross-section along $Y-Y^{\prime}$ in $B$ before (solid line) and after (dashed line) the landslide. d) Cross section along $X-X^{\prime}$ in $B$ before (solid line) and after (dashed line) the landslide. Numbers 1 and 2 correspond to the scarp numbers in (b). Numbers in parentheses are slope angles and horizontal lengths along the slope line. Slope images were made using high resolution DEMs by the Ministry of Land, Infrastructure, Transport and Tourism.

features are similar to the "rock bridges" described by Eberhardt et al. (2004). Chigira et al. (2013a) analyzed the internal structures of a gravitationally deformed slope with irregularly shaped depressions and protrusions, and proposed that following their nucleation gravitational shear zones develop and connect to each other to form a through-going shear zone, which appears as a small scarp on the slope surface along the head of the moving body of material. The small scarps before catastrophic failure may therefore indicate an incipient landslide.

Typhoon Talas also induced one landslide with a large headscarp on a dip slope of alternating beds of sandstone and mudstone. This landslide had been gravitationally deformed with a buckle fold downslope (Chigira et al., 2013b). Buckle folds commonly accommodate large headscarps because the support from the lower slope at the lower limb remains even after a substantial amount of deformation. However, if the lower limb is exposed to intense erosion or failure, even a small amount of gravitational deformation may be sufficient to cause a catastrophic failure of the whole slope. The Shiaolin landslide, induced by typhoon Molakot in 2009 in Taiwan (Tsou et al., 2011), is an example of this type of landslide. The Shiaolin landslide had a volume of 25 million $\mathrm{m}^{3}$ and demolished one village, causing over 400 fatalities.

The Ginsaugon landslide in Leyte, the Philippines, occurred without a clear trigger but had been preceded by about $700 \mathrm{~mm}$ of rainfall within the 10-day period before the landslide event (Evans et al., 2007). There is no report of whether this landslide had distinctive precursory topography, but judging from the nearby slopes and the fact that the landslide had a sliding surface along a spray fault of the 
creeping Philippine Fault (Evans et al., 2007), it is very likely that there was a small headscarp before the catastrophic event.

\section{Conclusions}

The geomorphological features of deep-seated catastrophic landslides are evaluated in this paper as a basis for hazard mapping. Potential sites of shallow landslides are generally difficult to identify because of the wide variations in both subsurface structures and properties, In contrast, deep-seated landslides are predictable in many cases on the basis of specific geological and geomorphological features. Recent studies of deep-seated landslides indicate that many such landslides were preceded by gravitational slope deformation, except in the cases of earthquake-induced landslides in pyroclastic fall deposits and some mudstones and carbonate rocks. Earthquakeinduced landslides in pyroclastic fall deposits, however, would be predictable by also specifying the materials that would slide or accommodate a sliding surface based on investigations of both volcanostratigraphy and material weathering. The other types of catastrophic landslide are preceded by gravitational slope deformation, which can be predicted using topographic features.

\section{Acknowledgements}

T. Kamai, Y. Matsushi, and C.-Y. Tsou of the Disaster Prevention Research Institute are thanked for helpful discussions, and some of the research results used in this paper was derived from collaborative research studies with these authors. C. Lim of the University of Kebangsaan, Malaysia and C. Tang of Chengdu University of Technology, China provided the statistics of landslide hazards in their respective countries.

\section{References}

Chigira, M., 1982, Dry debris flow of pyroclastic fall deposits triggered by the 1978 Izu-Oshima-Kinkai earthquake: the "collapsing" landslide at Nanamawari, Mitaka-Iriya, southern Izu Peninsula. Journal of Natural Disaster Science, v. 4, pp. 1-32.

Chigira, M., 1990, A mechanism of chemical weathering of mudstone in a mountainous area. Engineering Geology, v. 29, pp. 119-138.

Chigira, M., 1992, Long-term gravitational deformation of rocks by mass rock creep. Engineering Geology, v. 32, pp. 157-184.

Chigira, M., 2007, Site characteristics of gigantic landslides. Kinmiraisha, Nagoya, 256 pp.

Chigira, M., 2009, September 2005 rain-induced catastrophic rockslides on slopes affected by deep-seated gravitational deformations, Kyushu, southern Japan. . Engineering Geology, v. 108, pp. 1-15.

Chigira, M., 2013, Deep-seated catastrophic landslides - where are potential sites? Kinmiraisha, Nagoya, 231 pp.

Chigira, M., Hariyama, T., Yamasaki, S., 2013a, Development of deep-seated gravitational slope deformation on a shale dip-slope: observations from high-quality drillcores. Tectonophysics, v. 605, 104-113.

Chigira, M., Nakasuji, A., Fujiwara, S., Sakagami, M., 2014, Soil-Slide Avalanches of Pyroclastic Fall Deposits Induced by the 2011 off the Pacific Coast of Tohoku Earthquake. In: H. Kawase (Ed.), Studies on the Off the Pacific Coast of Tohoku Earthquake. Springer, Tokyo, pp. 6586.

Chigira, M., Tsou, C.-Y., Matsushi, Y., Hiraishi, N., Matsuzawa, M., 2013b, Topographic precursors and geological structures of deep-seated catastrophic landslides caused by Typhoon Talas. Geomorphology, v. 201, pp. 479-493.

Chigira, M., Wang, G., Wu, S., 2012a, Landslides induced by the Wenchuan earthquake. In: J.J. Clague, D. Stead (Eds.), Landslides Types, Mechanisms and Modeling. Cambridge University Press, Cambridge, pp. 383-392.

Chigira, M., Wang, G., Wu, X., 2012b, Landslides induced by the Wenchuan earthquake. In: J.J. Clague, D. Stead (Eds.), Landslides: Types, mechanisms and modeling. Cambridge University Press, Cambridge, pp. 383-392.

Chigira, M., Wang, W.-N., Furuya, T., Kamai, T., 2003, Geological causes and geomorphological precursors of the Tsaoling landslide triggered by the 1999 Chi-Chi Earthquake, Taiwan. Engineering Geology, v. 68, pp. 259-273

Chigira, M., Wu, X., Inokuchi, T., Wang, G., 2010, Landslides induced by the 2008 Wenchuan earthquake, Sichuan, China. Geomorphology, v. 118, pp. 225-238

Chigira, M., Yagi, H., 2005, Geological and geomorphological characteristics of landslides triggered by the 2004 Mid Niigata prefecture Earthquake in Japan. Engineering Geology, v. 82, pp. 202-221.

Crosta, G.B., Chen, H., Frattini, P., 2006, Forecasting hazard scenarios and implications for the evaluation of countermeasure efficiency for large debris avalanches. Engineering Geology, v. 83, pp. 236-253.

Crosta, G.B., Imposimato, S., Roddeman, D., Chiesa, S., Moia, F., 2005, Small fast-moving f low-like landslides in volcanic deposits: The 2001 Las Colinas Landslide (E1 Salvador). Engineering Geology, v. 79, pp. 185-214.

Cruden, D.M., 1989, Limits to common toppling. Canadian Geotechnical Journal, v. 26, pp. 737-742.

Dellow, G.D., Hancox, G.T., 2006, The influence of rainfall on earthquakeinduced landslides in New Zealand, New Zealand Geotechnical Society 2006 Symposium. Institution of Professional Engineers. Proceedings of technical groups / Institution of Professional Engineers New Zealand Nelson, New Zealand, pp. 355-368.

Dramis, F., Sorrisovalvo, M., 1994, Deep-seated gravitational slope deformations, related landslides and tectonics. Engineering Geology, v. 38(3-4), pp. 231-243.

Dunning, S.A., Mitchell, W.A., Rosser, N.J., Petley, D.N., 2007, The Hattian Bala rock avalanche and associated landslides triggered by the Kashmir Earthquake of 8 October 2005. Engineering Geology, v. 93(3-4), pp. 130-144.

Eberhardt, E., Stead, D., Coggan, J.S., 2004, Numerical analysis of initiation and progressive failure in natural rock slopes - the 1991 Randa rockslide. International Journal of Rock Mechanics and Mining Sciences, v. 41, pp. 69-87.

Evans, S.G., Bent, A.L., 2004, The Las Colinas landslide, Santa Tecla: A highly destructive flowslide triggered by the January 13, 2001, El Salvador earthquake. In: W.I. Rose, J.J. Bommer, D.L. Lopez, M.J. Carr, J.J. Major (Eds.), Natural hazards in El Salvador. Geological Society of America Special Paper, Boulder, Colorado, pp. 25-37.

Evans, S.G., Guthrie, R.H., Roberts, N.J., Bishop, N.F., 2007, The disastrous 17 February 2006 rockslide-debris avalanche on Leyte Island, Philippines: a catastrophic landslide in tropical mountain terrain. Nat. Hazards Earth Syst. Sci., v. 7, pp. 89-101.

Guzzetti, F., Carrara, A., Reichenbach, P., Cardinali, M., 1999, Landslide hazard evaluation: a review of current techniques and their application in a multi-scale study, Central Italy. Geomorphology, v. 31, pp. 181-216.

Hadley, J.B., 1964, Landslides and related phenomena accompanying the Hebgen Lake earthquake of August 17, 1959. U. S. Geol. Surv. Prof. Paper, v. 435, pp. 107-138.

Hansen, W.R., 1965, Effects of the earthquake of March 27, 1964 at Ancourage, Alaska. U. S. Geol. Surv. Prof. Paper, 542A, 68.

Hirano, M., Ishii, T., Fujita, T., Okuda, S., 1985, Geomorphological and geological characteristics of 1984 landslide hazard in Ohtaki village, Nagano Prefecture, Japan. Annuals of Disaster Preventin Research Institute, Kyoto Uiversity, v. 28, pp. 519-532.

Hsu, K.J., 1975, Catastrophic debris streams (sturzstroms) generated by rockfalls. Geological Society of America Bulletin, v. 86, pp. 129-140.

Huang, R.Q., 2011, Geo-engineering lessons learned from the 2008 Wenchuan 
earthquake in Sichuan and their significance to reconstruction. Journal of Mountain Science, v. 8(2), pp. 176-189.

Huang, R.Q., Fan, X.M., 2013, The landslide story. Nature Geoscience, v. 6(5), pp. 325-326.

Inoue, Y., Honsho, S., Matsushima, M., Esashi, Y., 1970, Geological and soil mechanical studies on the slides occurred during the 1968 Toakachioki earthquake in southeastern area of Aomori Prefecture. Central Research Institute of Electric Power Industry, Report, pp. 1-27.

Jibson, R.W., Harp, E.L., Michael, J.A., 1998, A method for producing digital probabilistic seismic landslide hazard maps: An example from the Los Angeles, California, Area. U.S.Geological Survey, 98-113 pp.

Jibson, R.W., Crone, A.J., Harp, E.L., Baum, R.L., Major, J.J., Pullinger, C.R., Escobar, C.D., Martinez, M., Smith, M.E., 2004m Landslides triggered by the 13 January and 13 February 2001 earthquakes in El Salvador. In: W.I. Rose, J.J. Bommer, D.L. Lopez, M.J. Carr, J.J. Major (Eds.), Natural hazards in El Salvador. Geological Society of America, Boulder, pp. 69-88.

Kamai, T., 1990, Failure mechanism of deep-seated landslides caused by the 1923 Kanto earthquake, Japan. Proceedings of the sixth International Conference and Field Workshop on Landslides, pp. 187-198.

Kilburn, C.R.J., Petley, D.N., 2003, Forecasting giant, catastrophic slope collapse: lessons from Vajont, Northern Italy. Geomorphology, v. 54, pp. 21-32.

King, J., Loveday, I., Schuster, R.L., 1989, The 1985 Bairaman landslide dam and resulting debris flow, Papua New Guinea. Quarterly Journal of Engineering Eeology, v. 105, pp. 257-270.

Kleber, M., Schwendenmann, L., Veldkamp, E., Rössner, J., Jahn, R., 2007, Halloysite versus gibbsite: Silicon cycling as a pedogenetic process in two lowland neotropical rain forest soils of La Selva, Costa Rica. Geoderma, v. 138, pp. 1-11.

Matsuura, S., Asano, S., Okamoto, T., 2008, Relationship between rain and/ or meltwater, pore-water pressure and displacement of a reactivated landslide. Engineering Geology, v. 101, pp. 49-49.

Montgomery, D.R., Dietrich, W.E., 1994, A physically based model for the topographic control on shallow landsliding. Water Resources research, v. 30-4, pp. $1153-1171$.

Montgomery, D.R., Schmidt, K.M., GreenbergH.M., DietrichW.E.. 2000, Forest clearing and regional landsliding. Geology, v. 28-4, pp. 311-314.

Morimoto, R., Nakamura, K., Tsuneishi, Y., Ossaka, J., Tsunoda, N., 1967, Landslides in the epicentral area of the Matsushiro earthquake swarm Their relation to the earthquake fault. Bull. Earthq. Res. Inst, v. 45, pp. 241-263.

Nakano, M., Chigira, M., Lim, C.-S., 2013. Landslides of pumice fall deposits induced by the 2009 Padang earthquake and the formation of halloysite, Japan Geoscience Union Meeting 2013, Makuhari, HDS06-02.

Okuda, S., Okunishi, K., Suwa, H., Yokoyama, K., Yoshioka, R., 1985, Restoration of motion of debris avalanche at Mt. Ontake in 1984 and some discussions on its moving state. Annual Report of the Disaster Prevention Research Institute, Kyoto University, v. 28, pp. 491-504.

Petley, D., 2012, Global patterns of loss of life from landslides. Geology, v. 40 , pp. $927-930$.

Petley, D., Dunning, S., Rosser, N., Kausar, A.B., 2006, Incipient landslides in the Jhelum Valley, Pakistan following the 8th October 2005 earthquake. Disaster Mitigation of Debris Flows,Slope Failures and Landslides, pp. 47-55.

Sassa, K., Hiroshi, F., Scarascia-Mugnozza, G., Evans, S., 1996, EarthquakeInduced-Landslides: Distribution, Motion and Mechanisms. Soil s and Foundations, pp. 53-64.

Sato, H.P., Hasegawa, H., Fujiwara, S., Tobita, M., Koarai, M., Une, H., Iwahashi, J., 2007, Interpretation of landslide distribution triggered by the 2005 Northern Pakistan earthquake using SPOT 5 imagery. Landslides, v. 4(2), pp. 113-122.

Scheidegger, A.E., 1973, On the prediction of the reach and velocity of catastrophic landslides. Rock Mechanics, v. 5, pp. 231-236.

Schneider, J.F., 2008, Seismically reactivated Hattian slide in Kashmir, Northern Pakistan. Journal of Seismology, v. 13(3), pp. 387-398.

Seed, H.B., Wilson, S.D., 1967, The Turnagain Heights landslide, Anchorage, Alaska. Journal of theSoil Mechanics and Foundations Division, Proceedings of the American Society of Civil Engineers, pp. 325-353.

Sibson, R.H., 1996, Structural permeability of fluid-driven fault-fracture meshes. Journal of Structural Geology, v. 18, pp. 1031-1042.

Suzuki, T., 1993, Stratigraphy of Middle Pleistocene tephra layers around Nasuno Plain, in north Kanto, central Japan. Journal of Geography, v. 102(1), pp. 73-90.

Tanaka, K., 1985, Features of slope failures induced by the Naganoken-Seibu Earthquake, 1984. Tsuchi-to-Kiso, v. 33(11), pp. 5-10.

Toda, S., Tanaka, K., Chigira, M., Miyakawa, K., Hasegawa, T., 1995, Coseismic behavior of groundwater by the 1995 Hyogo-ken nanbu earthquake. Jishin, v. 48, pp. 547-553.

Tsou, C.-Y., Feng, Z.-Y., Chigira, M., 2011, Catastrophic landslide induced by Typhoon Morakot, Shiaolin, Taiwan. Geomorphology, v. 127, pp. 166178

Voight, B., Janda, R.J., Glicken, H., Douglass, P.M., 1983, Nature and mechanics of the Mount St Helens rockslide-avalanche of 18 May 1970. Geotechnique, v. 33, pp. 243-273.

Waitt, J., R.B., Pierson, T.C., Macleod, N.S., Janda, R.J., Voight, B., Holcomb, R.T., 1983, Eruption-Triggered avalanvche, flood, and lahar at Mount St.Helens-Effects of winter snowpack. Science, v. 221, pp.1394-1397.

Wang, W.-N., Furuya, T., Chigira, M., 2003, Geomorphological Precursors of the Chiu-fen-erh-shan Landslide Triggered by the Chi-chi Earthquake in Central Taiwan. Engineering Geology, v. 69, pp. 1-13.

Yoshida, M., Chigira, M., 2012, The relation between weathering of pyroclastic fall deposits and the collapses caused by the 1968 TokachiOki earthquake. Jour. Japan Soc. Eng. Geol., v. 52, pp. 213-221. 